\title{
A Study of Innovative and Creative Curriculum System Based on Quanzhou Maritime Silk Road Culture
}

\author{
Wang Xinghe ${ }^{1}$ \\ ${ }^{1}$ School of Cultural Communication, Liming Vocational University, Quanzhou, Fujian 362000, China
}

\begin{abstract}
Innovative Creativity Course is a learning system with students as the main body and innovation as the carrier.This study analyzes the necessity of integrating regional culture into innovative and creative curriculum, and illuminates the cultural characteristics of Quanzhou Maritime Silk Road (MSR) from the perspective of regional culture. On this basis, this study proposes that innovation-driven curriculum contributes significantly to the cultivation of qualified designers, and summarizes the four approaches (i.e., deepening of the integration of education and industry and establishment of the integrated teaching group, set-up of distinguished teacher and master studios for MSR culture, promotion of the model of shared curriculum resources, and advancement of the construction of the patent pool for the branded MSR culture) implemented to facilitate the pedagogical reform of innovative and creative curriculum and thus provide a solid theoretical and practical foundation for students to engage in design work.
\end{abstract}

\section{Introduction}

Over these years, multiple studies investigated Quanzhou Maritime Silk Road (MSR) culture from the perspectives of cultural self-confidence, religious relics, and branding construction. In regard to cultural self-confidence, a study suggests that the introduction of Quanzhou MSR culture using a lively approach into education in colleges and universities can remarkably elevate the core competitiveness of local colleges and universities [1]. With respect to religious relics, a study reveals that there is a valuable spiritual wealth left as a result of the cultural convergence and integration of Eastern and Western civilizations in Quanzhou [2]. In terms of branding construction, a study explores the path of Quanzhou's branding construction and development through sorting out the historical context of Quanzhou overseas transportation and the spiritual connotation of MSR [3]. To date, numerous achievements have been obtained in the studies on Quanzhou MSR culture. However, most studies focus on the inheritance and development of Quanzhou MSR culture, and studies on the practical implementation of Quanzhou MSR culture (e.g., the study on innovative and creative curriculum) are rarely reported. "Regional culture is a spiritual power, the soul of a nation, a regional taste, and an urban image [4]". The integration of regional cultural elements into innovative and creative curriculum can make curriculum and teaching more interesting and the product design increasingly novel, help students to gain an in-depth understanding and recognition of regional culture, enhance students' national sense of pride, expedite the upgrading of cultural and creative industries, and provide a reference for the government to formulate relevant policies.

\section{Regional culture-based innovative and creative curriculum}

\subsection{Curriculum enjoyment and design novelty}

Since religious beliefs and cognitions of life in different regions vary greatly, regional culture, a resource library containing various distinctive design materials, shows very typical regional characteristics. To integrate regional cultural elements into innovative and creative curriculum, a field investigation is required to sort out, analyze, and summarize the causes of the formation of regional culture, and integrate and summarize the resulting influences on humanities, customs and beliefs. Finally, such elements with typical characteristics are presented in an aesthetic way through design, to provide regional culture with novel connotations. In this process, students who have an indepth understanding can truly perceive the unique beauty of regional culture and increasingly enjoy the curriculum. As the saying goes, "Of the nation, of the world", the curriculum design, which takes regional culture as its core, injects a new vitality to the products, showing a novelty.

\subsection{Recognition and sense of pride of national culture}

Since most of the domestic design courses were introduced from the western countries after the reform and opening-up, the artistic philosophies are mostly interpreted following the traditional western way of 
thinking. Additionally, the western art culture significantly outweighs traditional Chinese national culture regarding the education of design physiologies. Such curriculum arrangement easily leads to students' insufficient understanding of local regional culture. As a result, they are prone to "turn a blind eye" to excellent regional culture in terms of design selection, and are more likely to select western design styles. The integration of regional cultural elements into innovative and creative curriculum enables students to learn and appreciate the artistic philosophies and aesthetic criteria of regional culture, enhance students' cultural awareness, innovation awareness, and recognition of national culture, cultivate students' sentiments, and improve students' sense of identity, belonging and national pride in regional culture.

\subsection{Cultivation and improvement of creativity}

In the context of "mass entrepreneurship and innovation", innovation-driven development has become a national strategic policy [5], and recruitment enterprises are always eagerly on the lookout for qualified innovative designers. Surveys on the job market in these three years have revealed the requirements of enterprises for the skillset of talents: creativity (100\%), software utilization skills $(66 \%)$, model construction skills (12.3\%), design communication skills (89.1\%), teamwork abilities (93\%), language proficiency $(9.2 \%)$, and production and processing skills $(11.2 \%)$. It shows that the abilities to spot problems and make innovations are valued by most enterprises. The integration of regional cultural elements into innovative and creative curriculum represents a reform and innovation in local regional culture, shows typical characteristics, aims at tapping students' creative potentials through cultivating their innovation abilities and striving to follow the emerging trends of science and technology development and social development, meets the requirements for adjustment of industrial structures, satisfies the demands for industrial development, is an outgrowth of the close integration of vocational education and industrial demands, and plays a stimulating role in industrial upgrading and governmental policy formulation.

Table1. List of National Key Cultural Relics Protection Units in Quanzhou

\section{Characteristics of Quanzhou MSR culture}

Urban cultural characteristics mirror regional culture to a certain extent. Quanzhou, home to the essence of the culture of the Kingdom of Min-yue, central plains culture, and oceanic culture, is the starting point of the MSR and one of the cities designated as National Famous Historical and Cultural Cities by the State Council of China, and has deep cultural and historical roots. Quanzhou has 802 historical and cultural sites protected at different levels, including 31 major historical and cultural sites protected at the national level, 98 major historical and cultural sites protected at the provincial level, and 601 intangible cultural heritages at all levels, making Quanzhou rank the top three in terms of levels and quantity of historical and cultural sites in China. Hence, Quanzhou is known for "Go to $\mathrm{Xi}$ 'an for underground historical and cultural sites and go to Quanzhou for historical and cultural sites on the ground". Additionally, there are 4 elements included in the list of the world's intangible cultural heritage and 31 intangible cultural heritages at the national level in Quanzhou [6]. Among them, there are two elements inscribed on the UNESCO(United Nations Educational, Scientific and Cultural Organization) Representative List of the Intangible Cultural Heritage of Humanity, one element inscribed on the UNESCO List of Intangible Cultural Heritage in Need of Urgent Safeguarding, and one element inscribed on the UNESCO Register of Good Safeguarding Practices of Intangible Cultural Heritage in Quanzhou, making Quanzhou become the only city in China with three major UN intangible cultural heritage projects ${ }^{[7]}$. Quanzhou MSR culture involves a wealth of knowledge of science, culture and history and fine works of art with great aesthetic values, which are the important knowledge sources of innovative and creative curriculum. Table 1 shows the list of major historical and cultural sites protected at the national level in Quanzhou, and Table 2 shows the list of the world's intangible cultural heritages in Quanzhou.

\begin{tabular}{|c|c|c|}
\hline $\mathrm{S} / \mathrm{N}$ & Batch & Name \\
\hline 1 & $\begin{array}{l}\text { The } 1^{\text {st }} \text { batch of } \\
\text { major historical and } \\
\text { cultural sites } \\
\text { protected at the } \\
\text { national level }\end{array}$ & $\begin{array}{l}\text { Qingjing Mosque (the Northern Song dynasty), Anping Bridge (the } \\
\text { Southern Song dynasty) }\end{array}$ \\
\hline 2 & $\begin{array}{l}\text { The } 2^{\text {nd }} \text { batch of } \\
\text { major historical and } \\
\text { cultural sites } \\
\text { protected at the } \\
\text { national level }\end{array}$ & $\begin{array}{l}\text { Kaiyuan Temple (Tang dynasty), Zheng Chenggong's Mausoleum } \\
\text { (Ming Dynasty) }\end{array}$ \\
\hline 3 & $\begin{array}{l}\text { The } 3^{\text {rd }} \text { batch of } \\
\text { major historical and } \\
\text { cultural sites } \\
\text { protected at the } \\
\text { national level }\end{array}$ & $\begin{array}{l}\text { Luoyang Bridge (the Northern Song dynasty), Tianhou Temple (the } \\
\text { Southern Song dynasty), Chongwu Ancient City Wall (Ming } \\
\text { dynasty), Stone Statue of Lao Tze (Song dynasty), Stone Inscriptions } \\
\text { at Mount Jiuri (Song dynasty), Site of Qudougong Dehua Kiln (Song } \\
\text { dynasty-Ming dynasty), Islamic Holy Tombs (Tang dynasty), Cao ' } \\
\text { an Temple } \\
\text { Statue of Mani (Yuan dynasty) }\end{array}$ \\
\hline
\end{tabular}


4 The $4^{\text {th }}$ batch of major historical and cultural sites protected at the national level

5 The $5^{\text {th }}$ batch of major historical and cultural sites protected at the national level

6 The $6^{\text {th }}$ batch of major historical and cultural sites protected at the national level

Confucius Temple of Quanzhou (Song dynasty-Qing dynasty),

Traditional Settlement of Cai-Clan (Qing dynasty)

Cizao Kiln Site (Song dynasty-Yuan dynasty), Genealogy of Ding Family in Chendai (Ming dynasty), Shi Lang Residence, Ancestral Temple and the Tomb (Qing dynasty), Deji Gate Site (Song dynastyMing dynasty), Zhenwu Temple, Liusheng Pagoda, Estuary Docks, Quanzhou Port Ancient Buildings (Song dynasty-Yuan dynasty), Anxi Confucian Temple (Qing dynasty), Sites of Anshan Sand Dunes in Jinjiang (Shang dynasty-Zhou dynasty),Five-Pagoda Rock Pagoda in Nan' an (Song dynasty) Qingshan Temple in Hui' an (Ming dynasty-Qing dynasty), Longshan Temple(Ming dynasty-Qing dynasty), Qingshui Yan Temple(Qing dynasty),Yang' amiao Former Residence (Qing dynasty), Former Residence of Lin in Nan' an(Qing dynasty), Zhongxiandi in Nan' an (Qing dynasty), Li Guangdi Ancestral Hall (Qing dynasty), Stone Buddha Statue in Xizi Temple in Jinjiang (Song dynasty), Stone Buddha Statue and Stone Inscriptions in Nantian Temple in Jinjiang (Song and Ming dynasties)

Table2. List of the world's intangible cultural heritages in Quanzhou

\begin{tabular}{cll}
\hline \multicolumn{2}{c}{ S/N } & \multicolumn{1}{c}{ Category } \\
\hline 1 & $\begin{array}{l}\text { Representative List of the Intangible } \\
\text { Cultural Heritage of Humanity }\end{array}$ & $\begin{array}{l}\text { Quanzhou Nanyin, Chinese Traditional } \\
\text { Architectural Craftsmanship for } \\
\text { Timber-framed Structures (Minnan } \\
\text { Residence) } \\
\text { The Watertight-bulkhead Technology } \\
\text { of Chinese Junks }\end{array}$ \\
& $\begin{array}{l}\text { List of Intangible } \\
\text { Cultural Heritage in Need of Urgent } \\
\text { Safeguarding } \\
\text { Register of Good Safeguarding } \\
\text { Practices of Intangible Cultural } \\
\text { Heritage }\end{array}$ & $\begin{array}{l}\text { Fujian Puppet Show Inheritors Training } \\
\text { Program }\end{array}$ \\
\hline
\end{tabular}

\section{Innovative and creative curriculum model based on Quanzhou MSR culture}

\subsection{Deepening of the integration of industry and education and establishment of the integrated teaching group}

Based on the manpower demands of enterprises pertaining to MSR, Quanzhou MSR culture-based innovative and creative curriculum is provided, the professional training program is adjusted, the relevant curriculum system is reconstructed, and the evaluation criteria are optimized. Additionally, the teaching group consisting of interdisciplinary teachers and technical professionals of enterprises is established based on the curriculum contents to break the professional boundaries of teachers and achieve the cooperation with enterprises, so as to cultivate students to be designers with MSR culture-based creativity who are competent for one post or multiple posts (See Table 3 Innovative teacher group).

Table3. Innovative teacher group

\begin{tabular}{|c|c|c|}
\hline \multicolumn{3}{|c|}{$\begin{array}{c}\text { Pre-reform schematic representation of the } \\
\text { structure of teachers } \\
\text { ("College } \rightarrow \text { Specialty } \rightarrow \text { Teachers") }\end{array}$} \\
\hline \multicolumn{3}{|c|}{ Specialty } \\
\hline $\begin{array}{c}\text { Industrial } \\
\text { design }\end{array}$ & Animation design & Graphic design \\
\hline $\begin{array}{l}\mathrm{A} 1, \mathrm{~A} 2, \mathrm{~A} 3, \\
\mathrm{~A} 4, \mathrm{~A} 5, \mathrm{~A} 6\end{array}$ & $\begin{array}{l}\mathrm{B} 1, \mathrm{~B} 2, \mathrm{~B} 3, \mathrm{~B} 4, \\
\text { B5, B6 }\end{array}$ & $\begin{array}{l}\mathrm{C} 1, \mathrm{C} 2, \mathrm{C} 3 \\
\mathrm{C} 4, \mathrm{C} 5, \mathrm{C} 6\end{array}$ \\
\hline $\begin{array}{l}\text { Post-re } \\
\text { (“College }\end{array}$ & $\begin{array}{l}\text {... } \\
\text { hematic repr } \\
\text { ucture of teac } \\
\text { lisciplinary tea } \\
\text { sionals of ente }\end{array}$ & $\begin{array}{l}\text { tion of the } \\
\text { and technical } \\
\text { ") }\end{array}$ \\
\hline
\end{tabular}




\begin{tabular}{|c|c|c|c|c|}
\hline \multicolumn{5}{|c|}{ Pre-reform schematic representation of the } \\
structure of teachers \\
("College $\rightarrow$ Specialty $\rightarrow$ Teachers") \\
Class category of college curriculum and specialty \\
modules \\
\hline $\begin{array}{c}\text { Market } \\
\text { research }\end{array}$ & $\begin{array}{c}\text { Hand- } \\
\text { painted } \\
\text { show }\end{array}$ & $\begin{array}{c}\text { Model } \\
\text { making }\end{array}$ & $\begin{array}{c}\text { Panel } \\
\text { design }\end{array}$ & $\ldots$ \\
\hline A1, B1, & A2, B2, & A3, B3, & A4, & A5, \\
\hline C1, & C2, & C3, & B4, & B5, \\
\hline & $\ldots$ & $\cdots$ & C4, & C5, \\
\hline$\ldots$ & & & $\cdots$ & $\cdots$ \\
\hline
\end{tabular}

Note: A, B, and C represent teachers of different specialties

\subsection{Set-up of distinguished teacher and master studios for MSR culture}

The studio is taken as a platform, where well-known masters with exceptional skills regarding MSR culture and relevant prestigious craftsmen are invited to give regular lectures. Additionally, apprenticeship education is adopted, the mentor group featuring the cultural creativity of MSR, where masters play a leading role and professional teachers play a coordinating role, is established, and the teaching model of "project + dualmentor system" is implemented, namely, the teaching model of "dual-mentor system", where the practical teaching of skilled masters and prestigious craftsmen and the design theories of professional teachers are integrated, is adopted to cultivate students" "craftsmanship spirit" and innovative creative abilities.

\subsection{Promotion of the model of shared curriculum resources}

Based on the development of regional industries, the construction of shared curriculum resources of MSR culture should be strengthened, namely, with the construction of granular resources as the focus and online resources (e.g., microlecture and massive open online courses) as the engine, the construction of the branded teaching resource library for MSR culture communication and creative design should be comprehensively promoted. Meanwhile, the cooperation with large enterprises associated with MSR culture should be concluded, so as to develop training curriculum resources that reflect the work-study characteristics, create a series of structured, shared, high-quality, and core curriculum related to MSR culture, and compile a series of innovative and creative loose-leaf textbooks associated with MSR Culture, so that students, enterprises and relevant social personnel can effectively benefit from MSR culture.

\subsection{Advancement of the construction of the patent pool for the branded MSR culture}

The innovative and creative curriculum resources related to MSR culture should be integrated. Based on relevant projects, teaching teams and studios, a sound pattern of participation of all teachers and students, support of special funds, and synchronous and step-wise promotion of appearance design, utility model design and patents for inventions should be established, and a number of patent pools featuring MSR culture should be constructed on schedule and purposefully. In this way, the creative rights and interests of teachers and students can be protected, and the school-enterprise cooperation can be carried out in the form of patent licensing and transfer, so as to achieve certain economic benefits, expand the influential effects of educational achievements of MSR culture, and further improve the will of involvement of teachers and students.

\section{Conclusion}

This study integrates and investigates regional culture and innovative design from the perspectives of regional culture and innovation-driven curriculum, and summarizes the four approaches(i.e., deepening of the integration of education and industry and establishment of the integrated teaching group, set-up of distinguished teacher and master studios for MSR culture, promotion of the model of shared curriculum resources, and advancement of the construction of the patent pool for the branded MSR culture) implemented to boost the sustainable development of local cultural and creative industries while nurturing students' innovative and creative abilities.

\section{Funded project:}

2020 Annual Project of the 13th Five-Year Plan for Fujian Provincial Education and Science Planning A Study of Innovative and Creative Curriculum System Based on Quanzhou Maritime Silk Road Culture (FJJKCG20-012); Cultivation Plan for Young and Middle-aged Heads of Disciplines (Specialties) in Colleges and Universities in Quanzhou

\section{References}

1. Wang X, Cai WG. The Education Construction of Quanzhou Maritime Silk Road Culture from the Perspective of Cultural Self-confidence[J]. Journal of Jilin TV \& Radio University, 2020(217):56-57.

2. Li YF. Religious and Cultural Heritage Nestorian Relics on Maritime Silk Road in Quanzhou[J].China Religion,2019:70.

3. Peng ZJ. The Explanation and the Expression of Maritime Silk Road Culture: Research on the Path of Quanzhou City Brand Construction under the Background of "the Belt and Road Initiative" [J]. Journal of Qingdao University of Science and Technology (Social Sciences),2018(34):13-14.

4. Wang Xing-he. The Research on Culture Resources and the Development of Cultural and Creative Industries of Quanzhou "Maritime Silk Road", 2019 (573) : 12007.

5. Li J. Investigation of the Basis for Construction of Innovation and Entrepreneurship Curriculum System 
in Local Colleges and Universities[J]. Data of Culture and Education, 2019(34):203-204.

6. Wu ZZ. A Study of the Feasibility of Tourism Development of Regional Cultural Heritage Resources-A Case Study on Quanzhou[D]. Quanzhou: College of Tourism, Huaqiao University, 2018.

7. Hu XS. Cultural Advantages of Quanzhou in Building the Pilot Area for the 21st Century Maritime Silk Road[J].Fujian Party History Monthly , 2018(06):14-15. 